\title{
TRANSLATING EARLY CHINESE TEXTS \\ AND THE PROBLEM OF CONTEXTUALIZATION: THE EXAMPLE OF CHAPTER 1 OF THE LǍOZ ${ }^{1}$
}

\author{
DUŠAN VÁVRA
}

\begin{abstract}
This article explores the issue of contextualization in translating early Chinese texts. It takes the example of Chapter 1 of the Lăožl, which is analysed sentence by sentence with the focus on possible contexts in which the sentences can be read. Three types of contexts are distinguished in the article - immediate textual context, edited context, and discursive context. While the former two types of context (paragraph, chapter, book) are evident and naturally taken into account in any translation, it is stressed in this article that the discursive context is often overlooked or at least not regarded properly. The article argues that discursive context is crucial for translating early Chinese texts in general, and in particular an ambiguous text like the Lăož̀.
\end{abstract}

Keywords: Laozi; translation; context; textuality; Chinese philosophy

1 This text was completed with the generous support of the Czech Science Foundation (GAČR), project no. GP14-24730P, "Cosmology and Self-cultivation in the Zhuangzi: Meaning Construction in Early Chinese Texts". 
Chapter $1^{2}$ of the Lăož 老子 $^{3}$ is one of the most famous pieces of early Chinese literature and also one of the most abstruse and difficult to translate. In the following, I use Wáng Bìs 王弨 received edition of the $L a ̆ o z \check{l},{ }^{4}$ which reads as follows: ${ }^{5}$

\author{
Dào kè dào fēi cháng dào \\ Míng kě míng fēi cháng míng \\ Wú míng tiān dì zhì shǐ \\ Yŏu míng wànwù zhī mǔ \\ Gù cháng wú yù y̌̀ guān qí miào \\ Cháng yǒu yù y̌̀ guān qí jiǎo
}

\author{
道可道非常道 \\ 名可名非常名 6 \\ 無名天地之始7 \\ 有名萬物之母8 \\ 故常無欲以觀其妙 \\ 常有欲以觀其敫9
}

2 Chapter 1 of the Lăož̀ in the received version of the text (for details about the extant editions, see notes 3 and 4). In the excavated manuscripts that contain this chapter (the Măwángdui 馬王堆 manuscript and Peking University manuscript; for details, see note 3), however, the chapter is placed in the middle of the text. In both manuscripts we find the order of two parts of the text - Dàojing (ch. 1-37 in the received text) and Déjing (ch. 38-81) - reversed.

3 The text is also known as the Dàodéjing 道德經 (The Canonical Book of the Way and Virtue). It is traditionally attributed to Lăož (“Old Fellow”) identified by Sīmă Qiān 司馬遷 as a Zhōu 周 royal archivist

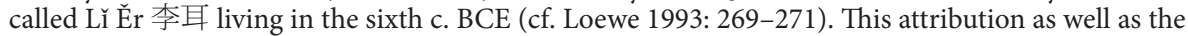
dating is usually not accepted in modern Western scholarship, which dates the origin of the text to the Warring States period (453-221 BCE), most likely the fourth c. BCE (see, e.g., Henricks 2000: 1-5). Furthermore, it is assumed that the text underwent a centuries-long period of formation before it was fixed in the received form during the Hàn 漢 dynasty (206 BCE - $220 \mathrm{CE}$ ). This process is fragmentally documented by the excavated Lăož manuscripts, namely the Măwángduī (MWD) manuscripts (early Western Hàn dynasty, 206 BCE - 9 CE), the Guōdiàn (GD) manuscripts (sealed in a tomb in ca. 300 BCE), and the Peking University (PU) manuscript (early Western Han). For a full translation and discussion of the Măwángduĩ Lăozĭ, see Henricks 1992; Lau 2001: 155-325. For the Guōdiàn Lăož̀ manuscripts, see Henricks 2000; Cook 2012: 189-322. For the Peking University manuscript, see the edition Běijīng dàxué 2012.

4 The textus receptus of Wáng Bìs Lăozl̆ is the edition most commonly used from premodern China up to now. There are several extant editions of the Lăož̆ - both received and excavated - as well as a number of modern critical editions. For an overview of the transmission of the text, see Loewe 1993: 271-286; Wagner 2003: 33-68. As for the name 'Wáng Bỉ’s Lăož̉, it refers to the most famous and influential commentary to the text by Wáng Bì (220-249 CE). It should be noted, however, that the textus receptus is actually different from the text Wáng Bì used, while it is virtually identical with another famous edition of the text with commentary - the Héshàng gōng Lăož̀ 河上公老子. See Wagner 2003, Loewe 1993.

5 This wording of the chapter is Wáng Bìs textus receptus. We find textual variants in this chapter in the Măwángduī manuscripts, the Peking University manuscript, and the "real” Wáng Bỉs Lăož̆, as reconstructed by Rudolf Wagner (2003). I add the different readings of each line in the following footnotes. Throughout this paper I quote Lăozľ chapters primarily from Wáng Bỉs textus receptus, unless a comparison with other editions is needed. Wáng Bi’s textus receptus is always quoted according to Lóu Yǔliè 2008.

6 Măwángduī manuscripts (both A and B): 道可道也, 非恒道也。名可名也, 非恒名也。See Gāo 1996: 221; Lau 2001: 266. The Peking University manuscript has 道可道, 非恒道也。名可命, 非恒 名也。The substitution of héng 恒 (which we find in both Western Hàn manuscripts) for cháng 常 (in all later editions) is due to a tabooing of the word héng after the death of Emperor Wéndì 文帝 (r. 180-157 BCE, personal name Liú Héng 劉恒).

7 Wáng Bỉs Lăozl̃ as reconstructed by Wagner: 無名萬物之始 (Wagner 2003: 119). MWD manuscripts: 无名萬物之始也。See Gāo Míng 1996: 222; Lau 2001: 266. PU manuscript: 無名萬物之始也。See Běijīng dàxué 2012: 144.

8 The MWD manuscripts and PU manuscript add a final yě 也 to this line, like in the previous lines. See Gāo Míng 1996: 222; Lau 2001: 266; Běijīng dàxué 2012: 144.

9 For these two lines, Măwángduī manuscripts A and B differ slightly from each other and contain several problematic characters. The two lines in the MWD reading can be summarized as follows (for details and discussion, see Gāo Míng 1996: 223-225): 故恒无欲也, 以觀其所眇。恒有欲也, 以觀其 所噭。The wording in the PU manuscript is almost similar; see Běijing dàxué 2012: 144. 
Cǐ liăng zhě tóng chū ér yì míng

Tóng wèi zhī xuán

Xuán zhī yòu xuán zhòng miào zhī mén
此兩者同出而異名 10

同謂之玄 11

玄之又玄眾妙之門12

When reading the existing translations of this text into various European languages, one basic observation can be made. The translators often include rich references to elucidate the complexities of the text at the lexical and syntactic level, as well as the complexities of the textual context (the chapter, or the Lăož as a whole). Seldom, however, does one encounter attempts at contextualizing individual terms or passages as belonging to specific discursive practices. ${ }^{13}$ The textual context of the book is often preferred, which adds to the idea of the unique nature of the text (created according to the traditional dating and status of the Lăož as the first book of Chinese philosophy). ${ }^{14}$ Besides, the context of "Daoism" is often employed, which is a retrospective term of doubtful value for reading Warring States texts.

The absence of discursive contextualization of individual terms or structures often results in translations that simply leave the text's vagueness not only unexplained (explanation may not be fully possible anyhow) but even untouched. I would argue, however, that the vagueness of an original text in Classical Chinese on one hand, and the vagueness of a modern translation on the other, is not the same thing - the translator always makes choices and in a vague translation these choices are simply not made clear to the reader. It must be the task of the translator to firstly understand the text itself in all its complexity and, secondly, transform this understanding into the target language (using footnotes or longer commentaries, if it is impossible directly through translation alone).

Compare, for example, the following translation of the beginning of chapter 1 by D. C. Lau (2001: 2-3):

The way that can be spoken of is not the constant way; the name that can be named is not the constant name. ${ }^{15}$

\section{道可道, 非常道。 名可名, 非常名。}

In D. C. Lau's book this translation is left practically uncommented; the translator does not answer the questions his translation may evoke:

(1) "The way that can be spoken of". We can easily base our understanding of "the way" on the context of the whole Lăož̆. The Lăož speaks frequently of "the true way"

10 Wáng Bỉs Lăož̌ as reconstructed by Wagner lacks the initial č̌ 此 (Wagner 2003: 120). The same is true for the MWD and PU manuscripts, which, in addition, omit ér 而. See Gāo Míng 1996: 227; Lau 2001: 266; Běijīng dàxué 2012: 144.

11 The MWD manuscripts connect this phrase to the previous line: 異名同胃。See See Gāo Míng 1996: 227; Lau 2001: 266. The same is true for the PU manuscript; see Běijīng dàxué 2012: 144.

12 MWD and PU: miào 眇 for miào 妙. See Gāo Míng 1996: 222; Lau 2001: 266; Běijīng dàxué 2012 : 144.

13 For example, the words dào 道 and ming 名 have variable and very distinctive discursive uses across the 'landscape' of early Chinese texts. I argue that we should ask, in the first place, what is the particular discourse at play in the given context, and translate the term or passage in light of it. See my discussion of 'discursive context' later in this paper.

14 In some translations, the syncretic nature of the Lăož̀ is stressed - see, for example, Lau 2001: ix-xl. Still, however, D. C. Lau's concern seems to be the unique nature of the syncresis, rather than discursive diversity.

15 We can find a very similar rendering of the first two lines in many other translations. Cf., for example, Krebsová 1997: 29; Král 1994: 39. 
(as compared to other "ways"), which guides processes in nature as well as the proper ordering of society. The phrase "that can be spoken of" is problematic - the book really "speaks of" it a lot. In the context of the Lăož̀ it is said repeatedly that the way cannot be “named” (bù kè míng 不可名), but kè míng is evidently different from kè dào.

(2) "Is not the constant way". "Constant" is a very vague term, and better contextualization of cháng is needed. Moreover, although there are chapters in the Lăož where the "true dào" the text speaks of is represented as something lasting from ancient times to the present, ${ }^{16}$ many other chapters (or sometimes the very same chapters) stress its abstruseness, imperceptibility, and changeability. ${ }^{17}$ There, we can ask, in what sense is it "constant"?

(3) "The name that can be named is not the constant name". If the meaning of "the dào that can be spoken of" is difficult to grasp and the "constant dào" too vague, this phrase then is a complete mystery. It makes no sense, and there are no other instances of "names being named" or "constant names" not only in the Lăozl but in the whole body of early Chinese literature. Moreover, this translation obviously parallels the "constant way" and the "constant name", as if both referred to some "constant" mysterious entity. There is, however no support for this reading in the Lăozĭ. On the contrary, the way is said to have “no constant name" (道無常名) in chapter 32 (Lóu 2008: 81).

Chapter 1 of the Lăož̀ is definitely difficult to translate. In this paper I do not intend to present just another translation, and surely not one I would consider "definitive" in the sense that it solves all the problems presented by the text. Instead, my ambition is to expose the textual and discursive possibilities we must consider when reading the chapter and thus present various possible contexts in which the chapter could be read. Indeed when translating a text written in classical Chinese, the translator has to make choices based on four types of contexts: the lexical and syntactic context, the immediate textual context, the edited textual context, and the discursive context.

First, the text must be fully decoded on the lexical and syntactic level. The words and their grammatical functions must be identified. For example, in the first line of the Lăož́, we get the following:

Dào kè dào, fèi cháng dào. 道可道, 非常道。

'Dào that can be dào-verbed, is not cháng-modified dào.'

This semi-finished translation makes the syntax of the sentence completely clear. The semantics is, however, not clear at all. Only the words kě 可 and fēi 非 can be unequivocally translated on the basis of a purely lexical and syntactic analysis. All the other words (left in pinyin within the English sentence above) require contextualization and cannot be translated without it.

Second, we must take into account the immediate textual context, which can further establish the meaning of a word. This context consists of a sentence or textual unit. ${ }^{18}$ It

16 Lăož̆ 14; 21. In: Lóu Yǔliè 2008: 31-32; 52-53.

17 Lăozl̆ 4; 8; 14; 21; 25; 41. In: Lóu Yǔliè 2008: 10; 20; 31-32; 52-53; 62-63; 111-113.

18 It is difficult to precisely define the term textual unit. Here I tentatively define it as a piece of text structured by internal criteria - a continuous narrative or dialogue, continuous exposition on a given topic. For the problem of "textual unit", see, e.g., Boltz 2005: 50-78. 
is, of course, often difficult to define what "immediate" means. I define it for the purpose of this paper simply as the section of a text that clearly forms a homogeneous statement (a piece of text that clearly "belongs together"). Usually, a sentence is a safe example of an immediate textual context, such as the following sentence from Master Lü's Spring and Autumn Annals:

Shāng wáng dà luàn, chén yú jiǔ dé. 商王大亂, 沈于酒德。

'The Shang king was extremely disordered and sunk into the power of alcohol.'19

In this sentence, the modifier jiǔ 酒 (alcohol) contextualizes dé 德 in a specific, less usual manner. It makes clear that power (dé) refers here to a distinct characteristic of alcohol (its power, the threat of alcohol addiction) and not, for example, to the virtuous qualities of a sagely ruler (a common meaning of dé). The immediate context, however, does not necessarily answer all the questions the text elicits - the text can be vague and equivocal, like, for example, the first sentence of the Lăozl̆ quoted above (and chapter 1 of the Lăož as a whole too). The immediate textual context can be a longer section of a text as well - a continuous narrative, dialogue, clearly framed exposition on a theme, a whole chapter. In these cases, however, questions about the text's integrity may arise that are difficult to answer - see below my discussion of the edited context.

The immediate textual context may also include certain formal features we often find in texts written in Classical Chinese, especially various forms of parallelism. ${ }^{20}$ These formal features are often key principles of textual construction and must be taken into account in the process of establishing meaning for a text. For example, the first two sentences of the Lăož are parallel, and this feature contributes substantially to the formation of the meaning of the text:

Dào kě dào, fēi cháng dào.

道可道, 非常道。 Míng kě ming, fēi cháng ming. 名可名, 非常名。

There are more parallel structures in chapter 1 of the Lăož̆, and their potential implications are complex. They will be discussed below.

Third, we must consider the edited textual context. All received early Chinese texts traditionally dated to the Warring States period (453-221 BCE) or earlier are edited. They certainly include a large amount of Warring States (or older) material, but some parts can be later (typically Western Hàn). Above all, though, the received form of this material in its entirety (for example, the Lăož̆) is the product of later editing during the Hàn dynasty or even later. ${ }^{21}$ The prevalent view in the recent scholarship has it that before the Hàn, the texts circulated as relatively short textual units and were put together in various ways over centuries of circulation. ${ }^{22}$ The excavated manuscripts corroborate

19 Lüshì chūnqiū 16/1.3. Knoblock and Riegel 2000: 374.

20 For various formal features contributing to the construction of meaning in early Chinese texts, see Gentz and Meyer 2015.

21 On text circulation and book formation in early China, see, e.g., Lǐ Líng 2004; Boltz 2005: 50-78; Fischer 2008-2009: 1-43; Meyer 2011; Richter 2013; Defoort and Standaert 2013.

22 It must be noted, however, that views on this question vary widely. There are influential scholars, both in China ad in Western academia, who tend to accept traditional dating and notions of authorship. 
this view. ${ }^{23}$ This interpretation means, above all, that received texts contain a great deal of heterogeneous material that may have originated at different times and in different social contexts and discursive practices. ${ }^{24}$

Acknowledging the composite nature of early Chinese texts has an unavoidable impact on translating them. If we read a text as a homogeneous whole, we naturally compare words and expressions across the text and build the translation within the context of the whole text. (In other words, we take the whole book as the immediate textual context.) But the composite nature of early Chinese texts problematizes this approach because different parts of the text may have originally belonged to different discourses and different textual practices, and may have even originated during different periods of time. Thus, the approach to translating early Chinese texts advocated in this paper is based on the conviction that it is the task of the translator to retain discursive differences, as long as they are discernible.

Having pinpointed the composite nature of early Chinese texts as a factor with crucial impact on the reading strategy we should adopt when approaching the texts, I must add the following: It does not mean that these texts cannot be read as books (as meaningful wholes). It only means that we must be more careful when reading a meaning into these texts. Just as we are supposed to read the texts closely, with perfect understanding of the complexities of the language in which they are written (Classical Chinese), I argue that we must be equally sensitive to the discursive practices that are at work in these texts.

Finally, the discursive context must be considered. For the reasons stated in the above discussion of the edited context, I believe it is necessary to establish the discursive context(s) for the text we are translating. In Classical Chinese many characters represent a number of different words with several meanings. Syntactic patterns in concrete cases are often open to multiple interpretations, and the textual context itself may not suffice to narrow the range of possible meanings either. Choosing the most appropriate meaning of a word and interpreting the syntax of a sentence often relies on correctly identifying the discourse the text represents.

The key questions we must ask when translating a text like the Lăož are: What are the actual discursive uses of a word, a term? Which of these are instantiated in the passage in question? In seeking out answers, it is necessary to realize that various discourses are spread across the Warring States texts and do not necessarily conform to the established classifications of "philosophical schools" or other traditional categories. While it may be viable to conceive of a "Confucian discourse", for example, it is probably less helpful to think of a "Daoist discourse", since "Daoism" is a much vaguer and more artificial category. ${ }^{25}$ Above all, however, many early Chinese discourses are shared across classifica-

For the Lăož̆, see, e.g., Lǐ Xuéqín 1995; Liú Xiàogăn 1994. Liú Xiàogăn is the main proponent of the traditional view in the West. See Liu 2014a.

23 See especially Richter 2013: 22-35.

24 I use the word discourse in the Foucauldian sense to mean a set of (usually unspoken) rules of what can be said in a given social and historical context. Foucault defines discursive practice as "a body of anonymous, historical rules, always determined in the time and space that have defined a given period, and for a given social, economic, geographical, or linguistic area, the conditions of operation of the enunciative function" (2004: 131).

25 For problems concerning the traditional categories of "philosophical schools", see Csikszentmihalyi and Nylan 2003; Smith 2003. 
tions of texts established ex post, and many do not have a "name" within the traditional classification framework.

Consider, for example, chapter 18 of the Lăož̆, where the discursive practice at play is quite evident but still, as we shall see, requires careful examination:

$\begin{array}{ll}\text { Dàdào fèi, yǒu rényì; } & \text { 大道廢, 有仁義; } \\ \text { Zhihuì chū, yǒu dàwěi; } & \text { 智慧出, 有大偽; } \\ \text { Liùqīn bù hé, yǒu xiàocí; } & \text { 六親不和, 有孝慈; } \\ \text { Guójiā hūnluàn, yǒu zhōngchén. } & \text { 國家昏亂, 有忠臣。 }\end{array}$

When the great way is discarded, morality appears.

When there is intelligence, great deceitfulness appears.

When the clan is not in harmony, loving care for parents appears.

When the state is in disorder, loyal ministers appear. ${ }^{26}$

This piece of text is rather unproblematic, and it is basically translatable on the lexical and syntactic level. ${ }^{27}$ The expression liuqin 六親 presents the only problem. Most modern interpreters follow the medieval commentators, who, beginning with Wáng Bì, understood this term to mean 'the six family relations', that is, the relationships between father and son, older and younger brothers, husband and wife. ${ }^{28}$ There are, however, a few earlier instances of this expression, dating mostly to the Hàn dynasty but also possibly to the Warring States. One of the earliest, found in Jiă Yìs 賈誼 (ca. 200-169 BCE) Xìnshū 新書 actually contains a rather detailed description of the term, which differs from that of later commentators. According to the Xinshü, liuqin refers to the six generations of one's clan as they stem from one "father" to the next generation. ${ }^{29}$ The meaning of the term thus seems to be simply 'clan' (or 'kin'), similar to the more frequent jiǔzú 九族. The other Hàn or Warring States occurrences of the term are less specific but seem to confirm the Xìnshī interpretation rather than that of later commentators. ${ }^{30}$

A full understanding of the chapter requires discursive contextualization. The text contains substantive references to the Confucian discourse; it discusses morality (rényi), loving care for parents (xiàocí), and loyal ministers (zhōngchén). These three concepts associated with the Confucian discourse "appear" when another set of categories is abandoned or in a chaotic state - the great way (dàdào), the clan (liùqin), and the state. In the context of this chapter, the way clearly means "order". 31 The nature of this order is not specified, although it obviously is one that existed prior to the advent of Confucian val-

26 Lóu Yǔliè 2008: 43-45.

27 There is, however, an important textual problem. The second line of this chapter is missing from Lăozl̆ Guōdiàn manuscript C (see Cook 2012: 311-313). Some modern editions (e.g., Chén Gǔyìng 2009) omit it based on the GD manuscript. The following discussion of this chapter shows, among other things, that its parallelism and overall meaning would work better without the second line. The inclusion or omission of this sentence, however, does not make a difference to the argument here.

28 Wáng Bì: "'Six relations' refer to the relations between father and son, older and younger brothers, husband and wife.” 六親, 父子兄弟夫婦也. See Lóu Yǔliè 2008: 43.

29 See Xīn shū 8.4. Jiă Yì 2000: 317.

30 For example, Lièzľ 1.10: "There are people who leave their native village, part from their kin, abandon their family business, roam in the whole world and do not return back - what kind of people are they? “有人去鄉土, 離六親, 廢家業, 遊於四方而不歸者, 何人哉? In: Yáng Bójùn 1979: 27.

31 The complexities of the meanings of the word dào are discussed below in this paper. 
ues and institutions (and is thus "more natural"). This understanding of the ideal social order is in tune with many instances of the word dào in the edited context (of the Lăož́ as a whole). The same can be said of the "clan" (natural organization of the large family prior to the Confucian ordering of family relations) and the "state" (the natural, or "right" organization of human society prior to Confucian-style government). We find numerous instances of the clan and the state being organized "naturally" in the received Lăožr. In sum, this chapter critiques Confucian values and institutions - they are said to appear only when true order disintegrates. Identifying the discursive context (Confucian vs. "Laoist") is crucial for understanding this chapter.

The lexical problem concerning the expression liùqin discussed above has an impact on the discursive contextualization of the chapter that should not be overlooked. Some translations of this chapter insert the following addition to the text: "When the great way is discarded, [the idea of] morality appears" (they also amend the third and fourth sentences in a similar way). ${ }^{32}$ The insertion of "the idea of" (or "the concept of", "the demand of", etc.) suggests that the "natural" conditions stated in the left column of the text $^{33}$ already include the Confucian values stressed in the right column (probably in a "spontaneous", non-discursive way). It is as if Confucian family relations already existed in a "natural" state in the ideal human society, and the decline represented by Confucianism was just a less perfect way to the same goal marked by defining specific values and enforcing their realization in human society.

It is crucial to note that this common approach to the chapter is, first, brought to play solely by reading liùin as 'six family relations'. As we have seen, this reading is based on medieval commentators, Wáng Bì above all. If liùqin means 'six family relations', then the Confucian web of human relations is present already in the "natural" state, at least in rudimentary form. If we, however, read this expression as 'the clan', then there is nothing necessarily Confucian about the dào-clan-state triad. Second, the reading of Daoist texts as a sort of "spontaneous Confucianism", in the sense that they share values with it but differ in the ways to implement them (spontaneously by human nature in the Lăož or Zhuāngž̆, by enforcement in Confucian texts) is a specific discourse developed by xuánxué 玄學 thinkers in the third century CE. Wáng Bìs commentary, the origin of the "six family relations" commentarial entry to the liùin sentence, was one of the most important texts promoting this discursive practice.

Thus, two different discursive contexts are established for the chapter by choosing one of the two possible explanations of the expression liuqin. In one, the chapter is read simply as a critique of Confucian values. In the other reading, it is not a critique of the Confucian values as such but only of a certain way of implementing them in human society.

In the following, I will go through chapter 1 of the Lăož sentence by sentence and term by term and try to distinguish the possible contexts into which we can read the chapter.

32 E.g., Henricks 2000: 112; Sehnal 2013: 139; Král 1994: 49.

33 Except the second line, which is omitted in GD manuscript C. 
Dào kè dào, fẽi cháng dào. Míng kè míng, fēi cháng míng. 道可道, 非常道。名可名, 非 常名。

\section{(1) dào 道}

The character 道 refers to two words, dăo (written also 導) and dào. ${ }^{34}$ Dăo means 'to guide, lead' (somebody). Dào as a noun means 'way' in the physical sense (road), and it also has several abstract meanings, including 'method' (the correct way to do something), 'order' (the correct way of doing things implemented or realized in human society, the human body, or the natural world), and 'teaching' (the correct way of doing things expressed in words). As a verb, dào means 'speak', and it has several other verbal meanings linked to the concept of 'way': 'regard as the right way' or 'follow as the right way', 'walk through', and 'to be in conformity with the right way'.

When denoting the natural world order, dào is often used in a context traditionally understood as "Daoist" and associated primarily with the Lăož̀. ${ }^{35}$ In this discursive context, dào refers to hidden principles of the world (of reality as whole) and simultaneously to a source of life through which everything exists (sometimes even conceived of as a metaphysical entity beyond the empirical world). In this cosmological discourse, dào has the following characteristics: ${ }^{36}$

- It is more fundamental than other traditional cosmological categories. (It was here before Heaven and Earth, it shelters Heaven and supports the Earth, etc.)

- It cannot be grasped with senses and cognition. (It is "empty", "formless", etc.)

- It has universal characteristics; it is both big and small, and so forth. ("Unroll it, and it blankets the six directions, roll it up, and it is less than a handful." ${ }^{37}$ )

- Things are born of it and raised by it; everything becomes what it naturally is by virtue of it ("by virtue of it, mountains are high"38).

- If the ruler rules by means of the dào, the world is in order.

In sum, the dào is omnipresent but invisible and unknowable; it is the hidden principle or structure of reality. It is manifested in the world by the fact that the world is orderly mountains are high, valleys are low, animals fly, fish swim, and so forth. The dào makes every single thing what it is. In some texts, in this context it is called the dé 德, 'the inner natural characteristics of every being..$^{39}$ The dào is universal, the dé is particular; the dé is the dào in things. ${ }^{40}$ This world-structuring power is, furthermore, usable by the sage-rul-

34 This short description of the semantic range of dào 道 is based on the Thesaurus Linguae Sericae.

35 Dào appears rarely with this meaning in the Zhuāngzi 莊子, but it is common in some later texts, like the Huáinánž 淮南子.

36 The most comprehensive and explicit account of this kind of cosmology is probably the "Original Dào" chapter (Yuán dào 原道) of the Huáinánž̀. See Lau and Ames 1998 for a full translation of this text.

37 “The Original Dao" (chapter 1 of the Huáinánzì). In: Lau and Ames 1998: 60-61.

38 Ibid.: 62-63.

39 Dé has several interrelated meanings: 'the inner natural characteristics of every being', 'inner power', or 'charisma'. All these meanings refer to substantial features of a thing or a person as manifested outwardly. The most common meaning, 'charisma' or 'virtue' of a ruler, indicates ruling by moral qualities (as manifested outwardly), in contrast to ruling by force.

40 The idea is explicitly expressed in this passage in "Techniques of Mind I" in the Guănž̆ (the text is corrupted, as is usual in the Guănž̆; in the following, various amendments and alternative readings have been proposed, according to Rickett 1998: 77 and Lí Xiángfèng 2004: 770-772): “The dào of heaven is empty and without shape. Being empty, it cannot be bent. Being without shape, it cannot be 
er and can be implemented to make order in human society as well (the meanings of cosmic order and method of government are typically interrelated). In the following, I call this dào-based cosmology the "cosmological discourse".

When reading and translating early Chinese texts, it is often very difficult to distinguish this cosmological discursive context from more common usages of the word dàoa specific order or method. Moreover, the characteristics of the cosmological dào summarized above can sometimes be applied to a specific dào as well. For example, in chapter 30 of the Guănž̆, we read the following:

\begin{abstract}
道者誠人之生也。非在人也。而聖王明君善知而道之者也。是故治民有常道, 而生財有 常法。

The way [of right government] truly produces men but it is not inherent in them. The sage kings and enlightened rulers are those who are good in understanding this and guiding them [the people] properly. Therefore, there is a constant way in governing people and there are constant models for producing wealth. ${ }^{41}$
\end{abstract}

In this passage, we learn of the "constant way" (cháng dào), and there is also a verbal use of the word dào. Both these features can be reminiscent of the first line of the Lăož́. It is only through the context of the chapter that we learn the dào here means a specific and practical method of government of a (broadly speaking) "Legalist" nature. Dào here clearly refers to specific methods of government only. Despite this, in another section of the chapter, the dào is said to have an “empty set-up" ( $x \bar{u}$ shè 虛設) - it exists only when embodied in the right ruler, and it cannot be embodied in reality and thus known to everyone. The image of the hidden and mysterious way pervades many discourses on government, not only the cosmological discourse.

In the Lăož̆, we find clear examples of the cosmological discourse but also many sections describing a way of government where the presence of the cosmological discourse cannot be ascertained. The following example from chapter 25 is definitely an instance of the cosmological discourse:

有物混成, 先天地生。 [...] 可以為天下母。吾不知其名, 強字之曰道, 強為之名曰大。

There is a thing born out of chaos, preceding the birth of heaven and earth. [...] It can be regarded as the mother of the world. I do not know its name but when forced to designate it, I call it "the way". When forced to name it, I call it "great". 42

opposed. This is why it permeates all things and does not change. Dé is the abode of dào. All things obtain it to live. The living beings obtain it so that they can perform [the behaviour allotted to them by] the essence of dào. Therefore ' $d e ́$ ' (= the natural characteristics of a given thing) means ' $d e ́$ ' (= obtain). 'To obtain' refers to the [characteristics] things obtain so that they are what they [naturally] are. When 'doing nothing', it is called dào. When abiding in things, it is called dé. This is why there is no difference between dào and dé. 天之道, 虛其無形。虛則不屈, 無形則無所位, 無所位, 故遍流萬 物而不變。德者道之舍, 物得以生。生知得以職道之精。故德者得也, 得也者, 其謂所得以然也, 以無為之謂道, 舍之之謂德。故道之與德無間。In: Lí Xiángfèng 2004: 770.

In Hánfèiž̀ 20 (chapter “Analysis of Lăož̌", Jiě Lăo 解老), a similar argument is made by using the opposites of dào and $l \grave{l}$ 理 (= 'structure'). In: Wáng Xiānshèn 1998: 146-147. For a Czech translation, see Zádrapa 2011: 275.

41 Guănž̉ 30. In: Lí Xiángfèng 2004: 563. The character 姓 in the original edition has been amended to 生, according to Lí Xiángfèng 2004: 563.

42 Lăozl̆ 25. In: Lóu Yǔliè 2008: 62-63. 
The following introductory sentence from chapter 37, however, can clearly be read in two ways:

\section{道常無為而無不為。侯王若能守之, 萬物將自化。}

(1) The true way is constantly doing nothing and still nothing is left undone. If the dukes and kings were able to keep to it, the myriad things would get civilized by themselves.

Or:

(2) The true way is to constantly do nothing and still nothing is left undone. If the dukes and kings were able to keep to it, the myriad things would get civilized by themselves. ${ }^{43}$

The idea of "doing nothing" in the Lăož can be applied to both the way and the ruler, and in this chapter both readings are possible. The import of the text is not changed much by choosing one translation over the other. We must be aware of the fact, however, that the former translation brings into play the cosmological discursive context, while the latter employs just the common meaning of a governance method. ${ }^{44}$ This is an important difference, which can be less clear in and have more important consequences for the translation of other passages.

Most interpreters of the Lăož̀ consider chapter 1 a clear instance of the cosmological discursive context. This view can be supported by the immediate context of the chapterthe "nameless" is described as "the beginning of all things, the mother of all things". These formulations clearly place the chapter within this cosmological discourse. The actual instance of dào in the first line can, however, still refer to specific governing methods. Choosing one of the discourses makes an important impact on the translation and eventually the whole meaning of the translated text. It will be demonstrated below.

The verbal form of dào in the first line of the Lăož can be translated in several ways: the way that can be spoken of, the way that can be walked, the way (the method of doing things) that can be followed, and the way that can be regarded as the true way. It is probably impossible to contextualize the expression kè dào, since it is not a part of a distinctive discourse. When trying to assess the possible translations of kè dào, we must turn to the modifier cháng, which can shed more light on it.

\section{(2) cháng 常}

Understanding the meaning of the modifier cháng (cháng dào) in chapter 1 of the Lăozl is no less important than comprehending other terms. This word has several interrelated meanings that all refer to regularity and predictability (= regular, as a rule, constant, enduring, normal, common, ordinary). Since dào means 'order', the first choice for translating cháng dào should probably be "regular, unchanging order" (or regular "way", of course). This might fit well into the context of many other expressions conveying the meaning of stable order ("regular laws", for example, cháng fă 常法).

43 Lăozǐ 37. In: Lóu Yǔliè 2008: 90-91.

44 The method of governance can be derived from the model of cosmological dào, which it clearly is in many instances in the Lăož̆. It does not change the important fact, however, that two different discourses are employed. 
Cháng can also be used as an abstract noun meaning 'regularity, regular procedure, regular principles'. Consider these two examples from the Hánféiž́:

\section{穆公問之曰:寡人嘗聞道而未得目見之也, 願聞古之明主得國失國何常以?}

The duke Mù [of Qín] asked him: "I have heard about the way but I have never seen it with my own eyes. I wish to hear about the regular principles by which the enlightened rulers of the ancient times gained and lost their states." 45

故先王以道為常, 以法為本。

Therefore the former kings took the way as the regular principle and the laws as their basis. ${ }^{46}$

These two sentences belong to a discourse (represented by the Hanféizi and many other texts) that emphasizes the importance of regularity in governance. The "way" (dào) is a natural part of this discourse, and its regular implementation in government is appreciated.

The Lăožl lacks comparatively clear passages. Sometimes, cháng is positive, but the immediate context is never clear. Cháng can also be negative, however, like in this passage from Lăož 49:

聖人無常心, 以百姓心為心。

The sage does not have a constant mind-set. He takes the people's mind-sets as his mindset. 47

This sentence brings into play another discourse, one associated with Legalist and Daoist writings, but above all with those texts that are traditionally labelled as "HuángLăo". ${ }^{48}$ This attribution is not without its problems, ${ }^{49}$ but, for the sake of convenience, in the following I will call this discourse the "Huáng-Lăo discourse". One of the principle ideas in this discourse is the absence of the ruler's "mind-set" (that is, intentions, plans, etc.), while the activity of the ruler rests in reacting to outer impulses only. In this dis-

45 Hánfēizľ 10. In: Wáng Xiānshèn 1998: 70.

46 Hánfēiž 19. In: Wáng Xiānshèn 1998: 126.

47 Lăozì 49. In: Lóu Yǔliè 2008: 129.

48 The attribution of specific texts to "Huáng-Lăo" is extremely problematic, and in this paper I refer to "Huáng-Lăo" as a type of discursive practice present in various texts classified usually as either "Daoist" or "Legalist". The most conspicuous feature of Huáng-Lăo discursive practice can be described as using "Daoist" terms in a clearly political fashion. For a more detailed discussion of the content of "Huáng-Lăo", see Chen and Sung 2014. The term Huáng-Lăo appears several times in Sīmă Qiān's Records of the Grand Scribe (Shiiji 史記) as well as in the History of the Western Hàn (Hàn$s h \bar{u}$ 漢書). Modern scholars often identify Huáng-Lăo with “Daoism”, as conceived of in these texts, which is supposed to be the principal understanding of Daoism during the Western Hàn dynasty. This is a political Daoism with a pronounced affinity for those thinkers identified as "Legalist". For this understanding of Huáng-Lăo, see Chen and Sung 2014 and other chapters related to Huáng-Lăo in Liu 2014b. The concept of Huáng-Lăo is set against the later (Eastern Hàn and onwards) concept of Daoism based on identification of the Lăož and the Zhuāngž̀ as the principal texts (in this categorization, a larger part of the Zhuāngzľ does not belong to Huáng-Lăo, see Liu and Wong 2014). It is this concept of "Daoism" that is still prevalent today (and not that of Huáng-Lăo, which is viewed as a distinct Western Hàn interpretation of Daoism).

49 For a thorough criticism of identifying the term Huáng-Lăo with Western Hàn Daoism (see the previous note) and a different definition of the term, see Ess 1993. 
course, it is wrong to be cháng because it is inflexible. The correct way of doing things is, on the contrary, based on flexibly reacting to changing circumstances.

So, if we get back to the first line of the Lăož - 道可道非常道 - how are we supposed to contextualize dào and cháng in this sentence? Based on lexical and syntactic considerations, three possible translations emerge:

(1) Dào that can be expressed in words is not the constant dào. In this variant, the first dào is negative, the second is positive ("the true way"). Cháng is positive too (the correct way is constant or regular). This reading assumes the true dào to be a regular principle or procedure, and it may be understood in the cosmological discursive context as well as in the context of specific governing methods. In this reading, dào refers to regularity in nature and in human society.

(2) Dào that can be followed (or: walked, regarded as the true dào) ${ }^{50}$, is not regular dào. In this reading, the first dào is positive (the true dào), and "cháng dào" is negative (regularity is unwelcomed). Again, the meaning of dào can be either cosmological or refer to governing methods.

(3) Dào that can be followed (walked, regarded as the true dào), is not an ordinary dào. ${ }^{51}$ This is a variant of the previous translation. Here the "true dào" is not denied a specific feature (regularity), like in the Huáng-Lăo discourse, but it is simply identified as 'not ordinary'. This translation seems to reference only government methods because it is hard to imagine the difference between "true" and "ordinary" in the cosmological context.

The nature of the difference between readings (1) and (2) is significant and it must not be overlooked. It reveals the discrepancies between two discourses that inform an immense portion of early Chinese thought: human action based on following regular principles versus human action based on the proper response to changing circumstances. ${ }^{52}$ This difference pervades a huge number of texts across various strands of Chinese thought. It is at least interesting to note that the first sentence of the Lăož̀ (known as a popular text open to many interpretations) can be read in line with both these discourses.

\section{(3) ming 名}

Ming means 'name' (noun) and 'to name' (verb). It also means 'fame' or 'reputation' in addition to having several other related meanings. This word figures prominently in a broad and common discourse, that of “matching names and realities" (ming shi 名實) or “correcting names" (zhèng ming 正名). ${ }^{53}$ This discourse is spread across a vast range of different texts of differing traditional classifications. It is concerned with proper "nam-

50 These possible translations have the same impact on the meaning, and we need not distinguish them.

51 This translation was suggested by Sehnal (2013: 80-82). Sehnal typically reads obscure passages in a way that rids them of any reference to a discursive context and establishes a sort of "down-to-earth", common sense interpretation. Cf., for example, Sehnal's reading of the first line of the famous chapter 40: "The right way produces the first thing, the first thing produces the second thing, [...], the third thing produces all things.” 道生一, 一生二, 二生三, 三生禹物。(Sehnal 2013: 215; translation from Czech by Dušan Vávra).

52 The former is represented, above all, by Legalism and Confucian ritualism, the latter by Huáng-Lăo, the five phases, or yīn-yáng discourses, many Daoist texts, especially the Zhuāngzž, and those strands in Confucianism that stress the personality of the "gentleman" (jünž̆ 君子) as the source of proper decision-making.

53 For a thorough discussion of the topic of "names and realities" in early Chinese thought, see Makeham 1994. 
ing," that is, attaching the correct names to the realities encountered or achieved. In texts traditionally categorized as "Legalist", matching names (that is, appointed tasks, orders, or promises) with achievements (the results of actual work on the task) is one of the principle methods of ruling. Confucians, on the other hand, were concerned with "correcting names". They believed that well-ordered rule depended on attaching the "true" names to (primarily) social realities. In both cases, naming is not just a formal task of "giving a name". It was believed that "naming" has a direct and profound impact on order in human society.

The sentence "míng kè míng, fèi cháng míng" is one of the most abstruse in the whole Lăož̀. Its meaning is already unclear on the lexical and syntactic level. First, as was noted by Sehnal (2013: 82-83), the common translation of "name that can be named" is grammatically wrong. Míng is a transitive verb and it forms the construction 'to name (call) somebody something. ${ }^{54}$ Thus, a name cannot be "named", but it can be "uttered." Míng, however, has a different meaning. The expression "cháng míng" (constant name) is less clear still, and it occurs nowhere else in early Chinese literature.

The sentence is parallel to the first sentence and thus should probably be read in similar syntax. This does not help much in understanding this passage, however, because the meaning of "name" is unclear (unlike dào).

The text of the Lăož̀ offers a possible clue for interpreting the expression kě míng. It is used several times in the text, and, apart from in chapter 1, it invariably refers to the dào that "cannot be named" (bù ké míng), that is, no name can be permanently attached to it. There are several instances of "naming" the dào as well, again with the characteristic emphasis on the provisional character of such naming.

The concept of “nameless" (wúmíng 無名) dào (and, analogically, of the sagely ruler) is a constituent of the Huáng-Lăo discourse mentioned above. In texts sharing this discourse, we can find a distinctive concept of "naming," which bears important resemblance to the Lăož̆. Consider the following quotation from "Cleansing the Mind" (Bái xìn 白心), a chapter from the Guănž 管子. 55 This text contains many difficult and probably corrupt sections, but its basic tenet is still quite evident. The text demands cleansing and quieting (jing 静) the mind, which must be devoid of all activity and only react to external stimuli. The ruler is quiet, inactive, and "nameless" (wúming) and only judges and classifies (attaches "names") to what is happening:

\section{是以聖人之治也, 靜身以待之, 物至而名之。正名自治, 奇名自廢。名正法備則聖人無 事。}

The governing of the sage is like this: He quiets his person and thus awaits what is coming. The things come and he attaches names to them. If the names are correct, things are put in order naturally on their own. If the names are not correct, things are abandoned naturally on their own. If names are correct and laws complete, the sage has no business. ${ }^{56}$

54 E.g., 名之以誰。“They called him a fraud."

55 "Cleansing the Mind" is one of the four "Daoist" texts from the Guănžl. The others are "Inner Training” (Nèiyè 內業) and the “Techniques of the Mind I-II” (Xìnshù shàng 心術上 and Xìnshū xià 心術 下). For a translation and discussion of these texts, see Rickett 1998: 15-97.

56 Bái xīn. In: Lí Xiángfèng 2004: 789. The original text amended according to Lí Xiángfèng 2004: 792-793. Cf. a similar passage in Hánfēiž̌ 5: "Thus [the ruler] remains empty and still and awaits 
As for the former sages, their mouth was not engaged in empty rehearsing, their hands were not engaged in empty pointing. Things appeared and they named them, and that was all. ${ }^{57}$

是謂寬乎刑, 徒居而致名。去善之言, 為善之事, 事成而顧反無名。能者無名, 從事無 事。審量出入, 而觀物所載。

This is called being lenient towards punishments, merely stay and wait and attach names [to things as they appear]. If [the ruler] abandons speeches about good and [instead] does good things, the things get completed and he reverts back to the "nameless". The capable ones are nameless [or: without fame] and in their undertakings they are without [their own] undertakings. They inspect going and entering and observe what things are carrying. ${ }^{58}$

In this text, the ruler is engaged in "naming", an important constituent act of his ruling practice. The ruler, however, remains hidden ("nameless", or perhaps, "without fame"), and the act of naming is presented as a spontaneous activity based on the nature of things and the circumstances of their appearance. The ruler's naming lies in properly reacting to situations at hand, without a rigid pre-established concept of naming. The ruler's being "nameless" can simply stress the fact that he is the source of naming (and is not "named" himself). It can also refer to his being without reputation. The ruler certainly engages in undertakings, but nevertheless he enacts them in such a way that his subjects have no knowledge of his ruling activity.

Can this analysis of the meaning of ming 名 be of any help when reading chapter 1 of the Lăozl? Let us check the translations of the second line against the translations of the first line stated above. Both are clearly parallel in the original and that is our main guideline to the abstruse second line.

(1) Dào that can be expressed in words is not the constant dào. This translation of the first line is commonly followed by the straightforward parallel line: The name that can be named is not the constant name. ${ }^{59}$ However, I really cannot see what this translation is supposed to mean. It is devoid of any context, even edited context. ${ }^{60} \mathrm{I}$ find the parallel between dào and ming in this rendering hopelessly obscure and I see no way to solve this problem. ${ }^{61}$

what is coming. He makes names name themselves and things fix themselves. Because he is empty he understands the true essence of things. Because he is still, he understands the movements of things." 故虛靜以待, 令名自命也, 令事自定也。虛則知實之情, 靜則知動者正。In: Wáng Xiānshèn 1998: 26. For a Czech translation, cf. Zádrapa 2011: 126.

57 Bái xīn. In: Lí Xiángfèng 2004: 802.

58 Bái xīn. In: Lí Xiángfèng 2004: 794.

59 Cf. Lau 2001: 3; Krebsová 1997: 29; Král 1994: 39.

60 As noted above, the problem of bù kè ming exists in the edited context but always in relation to dào, not "name". Additionally "constant name" does not appear in the Lăož or anywhere else.

${ }^{61}$ It must be noted, however, that Wáng Bỉs commentary (probably the oldest extant commentary to chapter 1 as a whole) puts forth this exact rendering. Nevertheless, Wáng Bì seems to be putting the commentarial entry in a way that deliberately avoids the problem: "A way that can be spoken about and a name that can be named refer to a demonstrable process and created shape, but not to their Eternal. This is because their Eternal cannot be spoken about and cannot be named.” 可道之道, 可名 之名, 指事造形, 非其常也。其不可道, 不可名也。(tr. Wagner; see Wagner 2003: 120-121). Wáng Bì comments on both dào and míng simultaneously and, moreover, takes míng as actually referring 
(2) If we read the first line as referring to governing methods (and, by extension, to the cosmology of the dào as well), we could arrive at the following translation, which stresses the ordering activity of the ruler in the social world: The way that can be followed (or: walked, regarded as the true way) is not a constant (regular) way. The names that can be regarded as true (right, correct) names are not regular (rigid, pre-established) names.

The Huáng-Lăo discourse, employed in this translation, puts to the fore the activity of the right ruler. The way is something to be followed by the ruler and it is not fixed the point is in responding flexibly to the changing circumstances. The "names" (or the ruler's act of naming) refer to the same order-making activity described more explicitly in the above passages from the Guănzl̆ chapter "Cleansing the Mind”. Again, the point is in flexible 'naming' according to the situation at hand.

The reading of the first sentence does not exclude the presence of the cosmological discourse in the text. The way that is followed by the ruler can still be the cosmological dìo, which would assume a close parallel between the functioning of the dào and the ruler. This is well-attested in the Lăož̆ as well as in other texts. In this reading, the cosmological meaning of the dào (the undifferentiated source of the differentiated, empirical reality) is linked with the concept of naming, which is analogous (naming as making order in the otherwise undifferentiated social world).

This translation has an undeniable advantage - it constructs a clear understanding of the parallel of dào and ming that is so strongly suggested by the original text, it constructs the parallel completely in all three positions of dào and ming, and, above all, it places the Lăož passage into a discursive context in which the terms and concepts used in the passage have a well-attested and well-defined meaning.

Wú míng, tiān dì zhī shŭ; yŏu míng, wànwù zhī mŭ. 無名, 天地之始; 有名, 萬物之母。

(1) wú míng 無名

The expression wú ming is found several times in the Lăož̆, as well as in many other texts. Wú míng can mean 'without fame'. As for the discourse of attaching proper names to realities, there are two possible lines of translation: "unnamed" or "being without naming". The former refers to the dào, or the position of the ruler. The latter refers to the dào's and the ruler's lack of ordering activity towards the world. Both are common in Daoist texts and the Huáng-Lăo discourse.

Furthermore, we can distinguish two basic connotations of wú míng found in different contexts: negative and positive. Negative connotations (it is wrong to be "unnamed" or "without naming") can be found in texts occupied with the need to properly name things, either in Legalist or Confucian fashion. Being "without proper naming" refers to a disordered society and chaotic state. In the Guănzĭ, for example, we find the following:

to named things ("created shapes"). In this reading a particular dào (process) and a particular thing both have their "that by which" they are created, called by Wáng Bì "cháng" (Eternal), among other expressions. It demonstrates a common feature of Wáng Bìs commentarial practice - reducing the plethora of (often obscure) images of the Lăož̌ into a well-defined set of terms. Cf. Vávra 2006. 


\section{名正則治, 名奇則亂, 無名則死, 故先王貴名。}

When the naming is correct, there is order. When the naming is deviant, there is chaos. When there is no naming at all, there is death. This is why the former kings valued proper naming. ${ }^{62}$

Positive connotations (it is good to be "unnamed" or "without naming") can be encountered in many Daoist texts and in the Huáng-Lăo discourse. In these texts, being 'unnamed' is a desired state but only for the ruler and the dào. The ruler is expected to keep in hiding and it is precisely his hidden position ("not being there": wú 無) that enables him to rule properly (and "name" properly, which can be interpreted as "not naming').

In the Lăož̀ (besides in chapter 1), the expression is invariably linked to the position of the dào or the ruler (or both):

\section{Chapter 32:}

道常無名。樸雖小, 天下莫能臣也。侯王若能守之, 萬物將自賓。[...] 始制有名, 名亦既 有, 夫亦將知止, 知止所以不殆。

The dào is constantly without naming. ${ }^{63}$ Although it is small in its simplicity, nobody in the world can subdue it. If the dukes and kings could keep to it, all the things would respectfully submit on their own accord. [...] When we start to regulate things, names/naming will appear. Names/naming being already there, we must know how to bring it to a halt. Bringing it to a halt is the way how to not get into danger. ${ }^{64}$

My translation of the first sentence, "the dào is constantly without naming", already presupposes the "naming" discourse being at play here. Of course, the translation might as well be "the dào is constantly without name". However, the whole context of the chapter (the immediate textual context) strongly suggests the activity of "naming" as a means to bring the world to order (the dào does it without naming; the ruler cannot dispense with naming but must be able to stop it in time).

The juxtaposition of wú míng and yǒu ming in this chapter presents an important edited context for chapter 1 . We will get back to it below.

Chapter 37 includes another interesting instance of wú míng in the Lăož̃:

道常無為而無不為。侯王若能守之, 萬物將自化。化而欲作, 吾將鎮之以無名之樸。無 名之樸, 夫亦將無欲。不欲以靜, 天下將自定。

The dào is constantly without action and still nothing is left undone ${ }^{65}$ If the dukes and kings were able to keep to it, all the things would get civilized on their own accord. If they get civi-

62 Guănzl̆, chapter 12, “Cardinal Sayings” (Shū yán 樞言). In: Lí Xiángfèng 2004: 242.

63 Other possible translations are "The dào is constantly without name" and "The right way is to be constantly without name/naming." The translations differ in whether they stress the dào or the ruler, and the state of being nameless or the (lack of) activity of naming.

${ }^{64}$ Lăož̉ 32. In: Lóu Yǔliè 2008: 81.

65 Or "The right way is to be constantly without action and still nothing is left undone." 
lized and desires still emerge, we will restrain them by means of simplicity without naming. Simplicity without naming will surely lead to absence of desires. If [we] do not [deliberately] desire to quiet them, the whole world will get stabilized by itself. ${ }^{66}$

This chapter is in many ways parallel to chapter 32 quoted above. Here, wú ming is explicitly associated with the ruler's activity, which supports the idea of "naming" as a plausible framework for translating ming. Being "without naming" is in this chapter the correct attitude on the part of the ruler that can prevent the world from reverting to chaos. "Naming", on the other hand, would be harmful.

\section{(2) yǒu míng 有名}

This expression is opposite to wú ming and refers to the presence of fame or names (or the act of naming). In the Lăož it occurs twice, in chapter 1 and chapter 32. Chapter 32 brings important edited context for chapter 1; yǒu míng is clearly presented in chapter 32 in the context of "naming", a governing activity of the ruler (see above).

\section{(3) shǐ 始 and $m \check{u}$ 母}

In chapter 1 , shĭ ('beginning') and mǔ ('mother') are paralleled:

The absence of names/naming is the beginning of heaven and earth. 無名, 天地之始。 The presence of names/naming is the mother of all things.

Wú míng and yǒu míng are evidently opposites. "Beginning" and "mother" should thus be read as opposite expressions in the same manner. "Absence of naming is the beginning of heaven and earth" can be read straightforwardly in the cosmological discursive context. The cosmological state before heaven and earth must be an undifferentiated state before anything was "born" and thus "named" (put in proper cosmological order). The relationship between yǒu ming and "mother" of all things is more complicated.

The expressions sh $\check{~}$ and $m \check{u}$ are similarly linked in chapter 52:

\section{天下有始, 以為天下母。既得其母, 以知其子, 既知其子, 復守其母, 沒身不殆。}

The whole world has a beginning that can be regarded as its mother. Once we get to the mother, we understand her progeny by it. Once we understand the progeny, we get back to hold on to the mother. Until the end we will not be in danger. ${ }^{67}$

The chapter makes clear an important distinction between "beginning" and "mother" because it makes explicit the close connection between the mother and the progeny, that is, in the cosmological framework, between the origin of things and the things. While "beginning" seems to be simply a beginning (an undifferentiated state before heaven and earth were born), "mother" refers to that beginning too, but stresses another aspect: the beginning retains a mother-like contact with the world of which it is the beginning and the mother.

66 Lăozǐ 37. In: Lóu Yǔliè 2008: 90-91.

67 Lăozĭ 52. In: Lóu Yǔliè 2008: 139. 
This difference is well in tune with the wú ming-yǒu ming distinction. "Beginning" belongs to wú ming (nothing yet there), while "mother" belongs to yǒu ming, the differentiated state (the empirical world being there). In other Lăož chapters, we find yet another similar distinction - that of dào and dé. Again, dào is associated with the "beginning", while dé refers to the nurturing aspect. ${ }^{68}$

As for the "naming", both the cosmological context and the Huáng-Lăo context are possible frameworks of this part of chapter 1. Naming can be cosmological (the birth of things from the undifferentiated state) or connected to ruling (the birth of naming, that is, governing). Moreover, it cannot be excluded that both these discursive contexts can be applied at once.

\section{Gù cháng wú yù, y̌̆ guān qí miào. Cháng yŏu yù, y̌̌ guān qí jiăo. 故常無欲, 以觀其 妙;常有行, 以觀其徽。}

Compared to the previous section of chapter 1, this one seems to follow a similar parallelism in juxtaposing cháng wú yù 常無欲 and cháng yǒu yù 常有欲. “Being constantly without desires" can thus be understood as parallel to wú ming and "being constantly with desires" as parallel to yŏu míng. The expression wú yù appears several times in the Lăozl in two immediate contexts: First, it is recommended to the ruler to keep the people "without desires" (wú yù). ${ }^{69}$ Then, the dào is said to be, or the ruler is required to be, "without desires" in order to rule properly. ${ }^{70}$

"Being constantly without desires" is meant to "observe its subtle points" (guān qí miào 觀其妙), “being constantly with desires” leads to “observing its fringes” (guān qí jiăo 觀其徼). I understand qí 其 here as referring to dào (the beginning and mother of all things), following most of the interpreters of the Lăož̆, whether pre-modern or modern ones.

The word miào can mean 'mystery', 'subtlety', and 'the subtle points of something'. It typically refers (just like its synonym, wei $i$ 微) to something difficult to grasp by discursive thinking but crucial to understanding the given problem. Thus, I understand it as 'subtle points', that is, that what is crucial to the way and difficult to understand. It can be understood only in the specific state of "being without desires".

Jiăo is a rare word found in chapter 1 and its interpretations vary widely. The only guidance we have is the parallelism of the text: jiăo should be opposite to miào. In this respect, it can mean 'to be marginal, peripheral', similar to the much more common mò 末 (tip of a branch). Thus, I understand "observing the fringes" as insight into the furthest manifestations of dào in the world. Together "observing miào and jiăo" refers to the capacity of observing reality, from its most minute subtleties the things originate in, up to the furthest fringes of reality's development.

68 See Lăož 10 and 51. In: Lóu Yǔliè 2008 2008: 22-24; 136-137.

69 Lăozľ 3. In: Lóu Yǔliè 2008: 8.

70 Lăozĭ 34, 37, 57. In: Lóu Yǔliè 2008: 85-86; 90-91; 149-150. 


\section{Cǐ liăng zhě, tóng chū ér yì míng, tóng wèi zhī xuán. Xuán zhī yòu xuán zhòng miào $z h i \bar{m}$ én. 此兩者, 同出而異名, 同謂之玄。玄之又玄, 眾妙之門。}

The last sentence of chapter 1 of the Lăož can be understood on the basis of lexical and syntactic analysis and the immediate textual context.

I present my translation first: "These two emerge together but differ in name. Together I call them mystery. Mysterious, and mysterious again, the gate of many subtleties."

I believe the interpretation of this final section is in fact the simplest of all from chapter 1, no matter how abstruse it may at first sound. The "two" can refer only to the repeated parallel "twins" from the previous part of the chapter: wú míng - yǒu míng, sȟ̆ - mǔ, wú yù - yóu yù. On the basis of the previous analyses it has already been repeatedly stated that these all express the twofold nature of the dào: it refers both to the primordial undifferentiated state before heaven and earth and to the nurturing state of "mother" of ten thousand things.

\section{Conclusion}

On the basis of the above analysis I present my own translation of chapter 1 of the Lăož̀:

\footnotetext{
The way that can be regarded as the right way is not a constant way.

The names that can be regarded as the right names are not constant names.

The absence of naming is the beginning of heaven and earth.

The presence of naming is the mother of all things.

Therefore, by being constantly without desires we observe its subtle points,

By being constantly with desires we observe its fringes.

These two emerge together but differ in name; together I call them mystery.

Mysterious, and mysterious again, the gate of many subtleties.
}

As we have seen throughout this paper, almost every line of this text can be translated in many ways. The translation presented here is thus one of many possible. The most important thing about this translation is not the individual decisions themselves but the way the decisions were made, by contextualization. Two types of contextualization were crucial in producing the translation: first, textual contextualization within the chapter (the chapter is interwoven with parallelisms that play a crucial role in the chapter's construction of meaning), and second, discursive contextualization (the first four lines were translated by finding context for its terms in other related texts).

Discursive contextualization must be emphasized as the most important method used in the translation. Several discursive contexts have been suggested for various terms in the text, especially for dào 道, míng 名, cháng 常, and wú míng 無名. Discursive contextualization is based on a reading of the Lăož as a part of larger discourses common in Warring States philosophical thought. The advantage of this approach lies in the disambiguation of the abstruse lines in chapter 1 of the Lăož̀. While not denying the ambiguity of this piece of text as such, the paper argues that the concrete solutions offered for the 
ambiguous text can convey a clear-cut and well-established meaning within the proposed discursive context.

\section{REFERENCES}

Ames, Roger T. and Hall, David L. (2003). Daodejing. A Philosophical Translation. New York: Ballantine Books.

Běijīng dàxué chūtǔ wénxiàn yánjiūsuǒ 北京大学出土文献研究所 (ed.) (2012). Běijīng dàxué cáng Xīhàn zhúshú (èr) 北京大学藏西汉竹书 (武) [Western Han Dynasty Bamboo Books Collected by Beijing University II]. Shànghăi: Shànghăi gǔjí chūbănshè.

Boltz, William (2005). “The Composite Nature of Early Chinese Texts.” In: M. Kern (ed.), Text and Ritual in Early China. Washington: University of Washington Press, 50-78.

Chén Gǔyìng 陳鼓應 (ed.) (2009). Lăož̉ jīn zhù jīn yi 老子今注今譯 [The Lăož̀ with Modern Commentary and Translation]. Běijīng: Shāngwù yìnshūguăn.

Chen, L. K. and Sung, Hiu Chuk Winnie (2014). “The Doctrines and Transformations of the Huáng-Lăo Tradition." In: Liu Xiaogan (ed.), Dao Companion to Daoist Philosophy. Dordrecht: Springer, 241-264.

Cook, Scott (2012). The Bamboo Texts of Guodian. A Study and Complete Translation. 2 vols. Ithaca: Cornell University Press.

Csikszentmihalyi, Mark and Nylan, Michael (2003). "Constructing Lineages and Inventing Traditions through Exemplary Figures in Early China." Toung Pao 89: 59-99.

Defoort, Carine and Standaert, Nicholas (2013). The Mozi as an Evolving Text. Leiden: Brill.

Ess, Hans van (1993). “The Meaning of Huang-Lao in Shiji and Hanshu.” Études Chinoises 12.2, 161-177.

Fischer, Paul (2008-2009). "Authentication Studies Methodology and the Polymorphous Text Paradigm." Early China 32, 1-43.

Foucault, Michel (2004). The Archeology of Knowledge. London: Routledge.

Gāo Míng 高明 (ed.) (1996). Bóshū Lăož̌ jiào zhù 帛書老子校注 [The Lăozǐ Silk Manuscripts Collated and Commented]. Běijīng: Zhōnghuá shūjú.

Gentz, Joachim and Meyer, Dirk (eds.) (2015). Literary Forms of Argument in Early China, Leiden: Brill.

Graham, Angus C. (1998). “The Origin of the Legend of Lao Tan.” In: L. Kohn and M. LaFargue (edd.), Lao-tzu and the Tao-te-ching. Albany: State University of New York Press.

Harbsmeier, Christoph (ed.). Thesaurus Linguae Sericae: An Historical Encyclopaedia of Chinese Conceptual Schemes [online]. Accessible at http://tls.uni-hd.de (accessed 02-10-2017).

Henricks, Robert G. (2000). Lao Tzu's Tao Te Ching. A Translation of the Startling New Documents Found at Guodian. New York: Columbia University Press.

Jiă Yì 賈誼 (2000). Xìnshū jiào zhù 新書校注 [The New Writings Collated and Commented]. Běijing: Zhōnghuá shūjú.

Knoblock, John and Riegel, Jeffrey (2000). The Annals of Lü Buwei. A Complete Translation and Study. Stanford: Stanford University Press.

Král, Oldřich (1994). Kniha mlčení. Praha: Mladá fronta.

Krebsová, Berta (trs.) (1997). Lao-c'. Tao te ting. Praha: DharmaGaia.

LaFargue, Michael (1994). Tao and Method. A Reasoned Approach to the Tao Te Ching. Albany: State University of New York Press.

Lau, D. C. (2001). Tao Te Ching. Hongkong: The Chinese University Press.

Lau, D. C. and Ames, Roger T. (edd.) (1998). Yuan Dao. Tracing Dao to Its Source. New York: Ballantine Books.

Lewis, Mark Edward (1999). Writing and Authority in Early China. State University of New York Press.

Lǐ Líng 李零 (2004). Jiănbó gǔshū yǔ xuéshù yuánliú 简帛古书与学术源流 [Ancient Books Written on Bamboo and Silk and the Origins of Scholarship]. Běijīng: Shēnghú, dúshū, xīnzhī sānlián shūdiàn.

Lí Xiángfèng 黎翔鳳 (ed.) (2004). Guănzǐ jiào zhù 管子校注 [The Guănzĭ Collated and Commented]. Běijīng: Zhōnghuá shūjú.

Lǐ Xuéqín 李学勤 (1995). “Shēnlùn Lăozĩ de niándài” 申论老子的年代 [Discussing the Datation of the Lăozǐ]. In: Dàojiā wénhuà yánjiū. Vol. 6. Shànghăi: Shànghăi gǔjí chūbănshè. 
Liú Xiàogăn 刘笑敢 (1994). “Lăozǐ zăochūshuō xīnzhèng” 老子早出说新证 [New Evidence for the Hypothesis of an Early Origin of the Lăozỉ]. In: Dàojiā wénhuà yánjiū. Vol.4. Shànghăi: Shànghăi gǔjí chūbănshè.

Liu, Xiaogan (2014a). “Did Daoism Have a Founder? Textual Issues of the Laozi”. In: Liu Xiaogan (ed.), Dao Companion to Daoist Philosophy. Dordrecht: Springer, 25-45.

Liu, Xiaogan (ed.) (2014b). Dao Companion to Daoist Philosophy. Dordrecht: Springer.

Liu, Xiaogan and Wong, Yama (2014). "Three Groups of the Outer and Miscellaneous Chapters". In: Liu Xiaogan (ed.), Dao Companion to Daoist Philosophy. Dordrecht: Springer, 221-237.

Loewe, Michael (ed.) (1993). Early Chinese Texts: A Bibliographical Guide. New Haven: The Society for the Study of Early China.

Lóu Yǔliè 樓宇烈 (ed.) (2008). Lăož Dàodéjīng zhù jiào shi 老子道德經注校釋 [Lăož̌s Dàodéjing Commented and Collated]. Běijīng: Zhōnghuá shūjú.

Makeham, John (1994). Name and Actuality in Early Chinese Thought. Albany: State University of New York Press.

Meyer, Dirk (2011). Philosophy on Bamboo: Text and the Production of Meaning in Early China. Leiden: Brill.

Richter, Matthias (2013). The Embodied Text: Establishing Textual Identity in Early Chinese Manuscripts. Leiden: Brill.

Rickett, W. Allyn (1985). Guanzi: Political, Economic, and Philosophical Essays from Early China. Vol. 1. Princeton: Princeton University Press.

Rickett, W. Allyn (1998). Guanzi: Political, Economic, and Philosophical Essays from Early China. Vol. 2. Princeton: Princeton University Press.

Sehnal, David (2013). Kniha Laozi. Překlad s filologickým komentářem [The Lăozǐ. A Translation with Philological Commentary]. Praha: Filozofická fakulta Univerzity Karlovy.

Smith, Kidder (2003). "Sima Tan and the Invention of 'Daoism', 'Legalis', et cetera." The Journal of Asian Studies 62.1, 129-156.

Vávra, Dušan (2006). "Wang Bi, Heshang gong, Xiang er. Různá čtení jednoho textu v tradičních komentáŕích k dílu Laozi." Religio 14.1, 41-68.

Wagner, Rudolf (2003). A Chinese Reading of the Daodejing: Wang Bi Commentary on the Laozi with Critical Text and Translation. Albany: State University of New York Press.

Wáng Xiānshèn 王先慎 (ed.) (1998). Hánfēiž̌ jijize 韩非子集解 [The Hánfèiž̌ with Collected Explanations]. Běiīing: Zhōnghuá shūjú.

Yáng Bójùn 楊伯峻 (ed.) (1979). Lièž jíshi 列子集釋 [The Lièzǐ with Collected Interpretations]. Běijīng: Zhōnghuá shūjú.

Zádrapa, Lukáš (tr.) (2011). Chan-fej-c’’ [Hánfēiž̃]. Sv. I. Praha: Academia. 